\title{
Diversity and structure of the woody component of a restinga in Alcântara, Maranhão State, Brazil
}

\author{
Eduardo Bezerra de Almeida Júnior ${ }^{a} \bullet$, Bruna Emanuele Freire Correia $\bullet$, Francisco Soares \\ Santos-Filhob \\ a Programa de Pós-Graduação em Biodiversidade e Conservação, Universidade Federal do Maranhão, São Luís, 65080-805, \\ Maranhão, Brasil.*ebaj25@yahoo.com.br \\ b Programa de Pós-Graduação em Desenvolvimento e Meio Ambiente, Universidade Federal do Piauí, Teresina, 64002-150, Piauí, \\ Brasil.
}

Received: September 30, 2019 / Accepted: December 27, 2019 / Published online: May 25, 2020

\begin{abstract}
Although Maranhão State has the second longest coastline of Brazil, phytosociological studies are necessary to expand the knowledge of the restinga vegetation therein. Thus, the present study characterizes structural parameters of the woody component of a restinga in Alcântara city, west coast of Maranhão State. The phytosociological sampling included thirteen 100 $\mathrm{m}$ parallel transects, totaling 50 points. The inclusion criterion established for the species was perimeter at ground level $\geq 10$ $\mathrm{cm}$. We sampled 34 species, 26 genera, and 17 families, totaling 200 individuals. The species with the highest importance value (IV) were Guettarda angelica Mart. ex Müll.Arg., Anacardium occidentale L., Myrcia splendens (Sw.) DC., Cenostigma bracteosum (Tul.) E. Gagnon \& G.P. Lewis, Fridericia sp., Eugenia stictopetala Mart. ex DC., and Mouriri guianensis Aubl. The average height of the specimens was $4.44 \mathrm{~m}$, and the average diameter was $12.6 \mathrm{~cm}$. The Shannon diversity index found in the restinga was 2.92 nat. ind ${ }^{-1}$, and Pielou's evenness was 0.83. It is worth mentioning the presence of Sapium glandulosum (L.) Morong and Manilkara bidentata (A.DC.) A.Chev, which are common species of the Cerrado and the Amazonian forest, respectively. Our findings contribute to the knowledge of diversity, generating data for the development of conservation studies, besides reinforcing the influence of the flora of neighboring ecosystems in the colonization of the restingas of Maranhão State.
\end{abstract}

Keywords: Importance value, northeast coast, species richness, woody component.

\section{Diversidade e estrutura da comunidade lenhosa de uma restinga no litoral de Alcântara, Maranhão, Brasil}

\begin{abstract}
Resumo
Apesar do Maranhão ser considerado o segundo maior litoral do país, estudos fitossociológicos são necessários para ampliar o conhecimento da vegetação das restingas do Estado. Assim, o presente estudo teve como objetivo caracterizar os parâmetros estruturais do componente lenhoso de uma restinga no município de Alcântara, Maranhão. Para a amostragem fitossociológica foram instalados 13 transectos de $100 \mathrm{~m}$ paralelos, totalizando 50 pontos com critério de inclusão de espécies foi o Perímetro à Altura do Solo $\geq 10 \mathrm{~cm}$. Foram amostradas 34 espécies, 26 gêneros e 17 famílias, em um total de 200 indivíduos. As espécies de maior valor de importância foram Guettarda angelica Mart. ex Müll.Arg., Anacardium occidentale L., Myrcia splendens (Sw.) DC., Cenostigma bracteosum (Tul.) E. Gagnon \& G.P. Lewis, Fridericia Mart. sp., Eugenia stictopetala Mart. ex DC. e Mouriri guianensis Aubl. A altura média dos espécimes foi de $4,44 \mathrm{~m}$ e o diâmetro médio foi de $12,6 \mathrm{~cm}$. O índice de diversidade de Shannon foi de 2,92 nat. ind ${ }^{-1}$ e a equabilidade de 0,83. Cabe ressaltar a presença de Sapium glandulosum (L.) Morong e Manilkara bidentata (A.DC.) A.Chev., que são espécies comuns de áreas de Cerrado e de Floresta Amazônica, respectivamente. Os dados apresentados contribuem para o conhecimento da diversidade, gerando dados para o desenvolvimento de estudos direcionados a conservação, além de reforçar a influência da flora dos ecossistemas vizinhos na colonização das áreas de restinga do Maranhão.
\end{abstract}

Palavras-chave: Valor de importância, litoral do nordeste, riqueza de espécies, componente lenhoso.

\section{Introduction}

Considered an extremely fragile ecosystem, the restingas in Brazil have had their vegetation suppressed by anthropogenic actions such as real estate speculation, planting of monocultures, and exploitation of resources (Machado \& Almeida Jr., 2019). The northeast region has the longest coastline in the country, with 3,306 km (Pinheiro, Coriolano, Costa \& Dias, 2008). However, considering its extension and 
plant heterogeneity (Machado \& Almeida Jr., 2019), there is still a need for further studies in this region (Santos-Filho, Almeida Jr. \& Zickel, 2013).

Located in northeastern Brazil, Maranhão State has the second longest coastline in the country, with $640 \mathrm{~km}$ (ElRobrini et al., 2006), and is inserted in a transition area between the northeast and the Amazon region. This region can be characterized as ecotonal due to the influence of the flora of the Amazon, Cerrado, and Caatinga ecosystems, providing a unique diversity for the state.

Some phytosociological studies have already been developed in this region, the majority addressing the herbaceous component. Among these, the following stand out: Amorim, Santos-Filho \& Almeida Jr. (2016), who carried out a phytosociological study in the dunes of Araçagi beach; Araújo et al. (2016), and Santos, Amorim \& Almeida Jr. (2019), in the dunes of São Marcos beach. Regarding the phytosociology of the woody component, the only published study to date was conducted by Machado and Almeida Jr. (2019), who described the structural arrangement of the Curupu restinga and analyzed the species similarity between different restinga areas.

In view of the environmental heterogeneity in Maranhão state, phytosociological approaches in restingas contribute with important data to preserve these areas (Dias \& Araujo, 2017). Accelerated suppression of vegetation and anthropogenic processes have contributed to the entry of ruderal/exotic species, becoming a threat to the native flora of coastal areas. This justifies the development of more targeted research to understand the structural organization of the woody component, contributing with data on the arrangement, distribution, recruitment, and regeneration of the coastal vegetation of Maranhão State. Thus, this study characterizes the structure of the woody component and describes the phytophysiognomy of the restinga vegetation on the coast of Alcântara, Maranhão State, Brazil.

\section{Materials and Methods}

\section{Study area}

The study was conducted in the restinga of Itatinga beach, Alcântara city, west coast of Maranhão State. The area is approximately $2 \mathrm{~km}$ long (Figure 1 ). According to the Köppen classification (1948), the climate of the region is Aw, with two defined seasons: a rainy season, from January to June; and a dry season, from July to December. The region has an average temperature of $26^{\circ} \mathrm{C}$ to $28{ }^{\circ} \mathrm{C}$, and annual rainfall of 2,000 $\mathrm{mm}$ (INMET, 2018).

According to the classification proposed by Santos-Filho, Almeida Jr., Soares \& Zickel (2010), the restinga of Itatinga beach has three physiognomies: nonflooded fields, open nonflooded shrublands, and closed nonflooded shrublands. Phytosociological analysis was performed only on the closed nonflooded shrublands physiognomy, characterized by shrub-tree vegetation, comprising the woody component of the area.

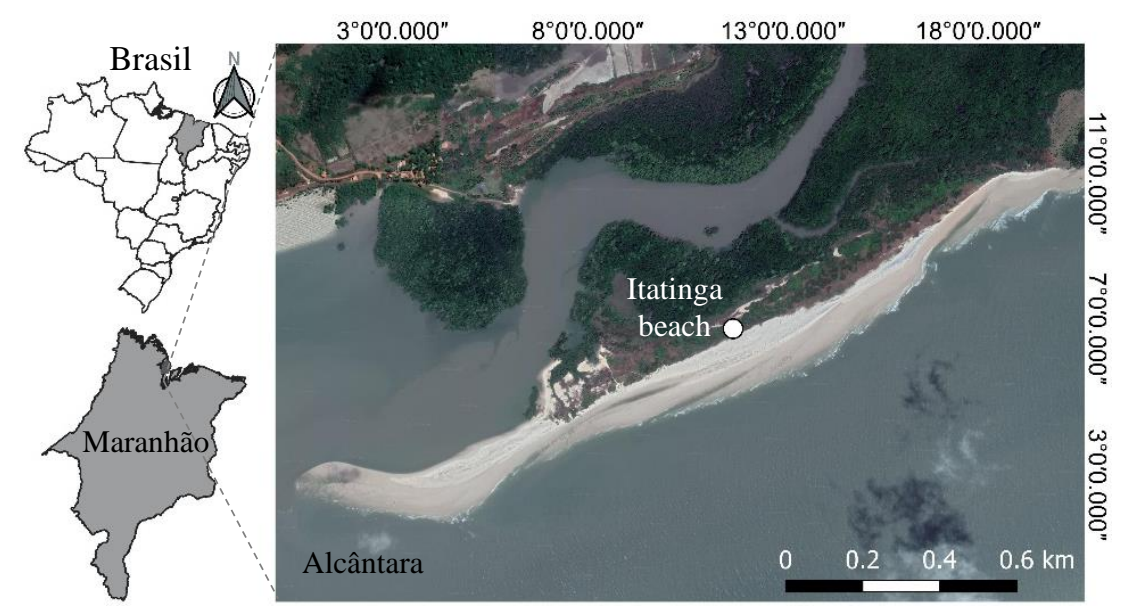

Figure 1. Restinga of Itatinga beach, Alcântara city, Maranhão State, Brazil. (Source: GoogleEarth - 2015; Prepared by: L. B. S. Costa).

\section{Sampling and data analysis}

The phytosociological study was conducted in July 2013, in the closed nonflooded shrublands physiognomy $\left(02^{\circ} 24^{\prime} 46.6^{\prime \prime} \mathrm{S}, 44^{\circ} 24^{\prime} 01.7^{\prime \prime} \mathrm{W}\right)$. For this, we used the pointcentered quarter method (Cottam \& Curtis, 1956). Due to plant formation, 13 transects were drawn in parallel, $10 \mathrm{~m}$ apart, all perpendicular to the beach line. In view of the cut of the restinga vegetation, 3 to 6 quadrant points were allocated in each transect, $10 \mathrm{~m}$ apart, being organized as follows: five transects with three points, six transects with four points, a transect with five points, and a transect with six points, totaling 50 sampling points. The present study followed the methodology that sampling 50 points in restingas already allow to achieve stability in the species curve. This methodology was used in different studies for the northeast coast (Medeiros et al., 2014; Zickel et al., 2015), enabling sampling standardization.

For the structural analysis of vegetation, woody individuals with perimeter at ground level (PGL) $\geq 10 \mathrm{~cm}$ were considered. In individuals branched at ground level, all branches were measured, the values being summed and transformed into a single value to represent the final diameter. The basal area of the plant was then calculated (Shepherd, 2010). The height of the sampled plants was 
measured by visual estimate. The botanical material was collected, herborized, and identified following the usual methodology (Mori et al., 1989; Peixoto \& Maia, 2013).

The list of families was organized following the proposal of APG IV (2016). Species were taxonomically identified by consulting the specialized literature (Pessoa \& Barbosa, 2012; Zappi et al., 2017; Mattos et al., 2018; Trindade, Rosário \& Santos, 2018; among others). Subsequently, we compared the identifications with the Herbarium collection and sent the material to specialists. Notwithstanding, some species were collected in the vegetative stage, rendering identification impossible. The nomenclature was checked on the Flora do Brasil 2020 website (http://floradobrasil.jbrj.gov.br) (http://floradobrasil.jbrj.gov.br/). The material was then incorporated into the collection of Herbarium of Maranhão (MAR), Department of Biology, Federal University of Maranhão (UFMA).

After sampling, the following phytosociological parameters were calculated: relative density (RD), relative frequency $(\mathrm{RF})$, relative dominance (RDo), importance value (IV), and coverage value (CV), all determined according to Mueller-Dombois \& Ellenberg (1974), besides the Shannon index (H'), Pielou's evenness (J'), and total richness (S). All phytosociological parameters were calculated using the Fitopac 2.1 software (Shepherd, 2010). Tables with the number of individuals were also organized by intervals of height (amplitude of 1 meter) and diameter (amplitude of $10 \mathrm{~cm}$ ).

\section{Results and Discussion}

A total of 34 species, 26 genera, and 17 families were identified (Table 1), with 200 individuals sampled. Of the total species, six remained as morphospecies (two species identified only as family, and four species maintained as indeterminate). The families with the highest species richness were Rubiaceae (six species), Fabaceae (four species), and Anacardiaceae, Erythroxylaceae, Myrtaceae, and Sapotaceae (two species each). The sum of the species of these families correspond to $52.9 \%$ of the total richness.

When studying different restingas in Pernambuco, some authors also highlighted the families Rubiaceae, Myrtaceae, and Fabaceae as more representative due to the wide distribution and phenotypic plasticity of the species (Almeida Jr., Olivo, Araújo \& Zickel, 2009; among others).

The species richness values of the present study were similar to those found by Machado and Almeida Jr. (2019), who listed 32 species when studying the woody vegetation of the shrub-tree physiognomy on Curupu Island, Maranhão State. On the other hand, our study showed a higher value when compared to the restingas of Piauí State, in which Santos-Filho et al. (2013) reported low values for the woody component in Ilha Grande (12 species), Parnaíba (18 species), and Luiz Correia (23 species). Moreover, the values were lower when compared to those observed in the coast of Pará State, where 41 species were listed (Santos et al., 2003).

The average height of the individuals was $4.44 \mathrm{~m}$ (standard deviation of $\pm 2 \mathrm{~m}$ ), with a maximum height of $15.7 \mathrm{~m}$ and a minimum of $1.45 \mathrm{~m}$. Of the total number of individuals sampled in the study area, $67 \%$ had a height between 2 and $5 \mathrm{~m}$ (Table 2), with higher prevalence of individuals 4 to 5 $\mathrm{m}$ high (Table 2). Species Agonandra brasiliensis $(10 \mathrm{~m})$, Anacardium occidentale $(11.5 \mathrm{~m})$, and Sapium glandulosum $(15.7 \mathrm{~m})$ were the tallest in the woody component of the studied physiognomy. The tallest individuals have spaced, branched crowns, and emerging species do not stand out due to the approximate height of many arboreal individuals and the similarity between the crown and stem of these plants.

The average diameter of the individuals was $12.76 \mathrm{~cm}$ (standard deviation of $15.6 \mathrm{~cm}$ ), with a maximum value of $167.4 \mathrm{~cm}$ and a minimum of $3.18 \mathrm{~cm}$. Most individuals were recorded in the first diameter class, with values from 3 to 13 $\mathrm{cm}$; and in the second diameter class, with values from 13 to $23 \mathrm{~cm}$ (Table 2). The diameter distributions of the present study were similar to the pattern of forests areas, with most individuals concentrated in the first diameter classes and a gradual decrease in larger diameter classes (Machado \& Almeida Jr., 2019). This distribution was also demonstrated in the study of Machado and Almeida Jr. (2019) in a restinga in Maranhão State. The authors highlighted a woody component with thinner, branched, and medium stems, which characterize the physiognomic formation of closed shrublands.

The sampling resulted in an average distance of $1.95 \mathrm{~m}$ between individuals, corresponding to a total density of 2,644.46 ind.ha ${ }^{-1}$, and dominance of 69.64.

The following community arrangements stand out with the highest number of individuals per family: Rubiaceae (68 individuals), with most records of Guettarda angelica (43); Myrtaceae (25), with most records of Myrcia splendens (14); Fabaceae (24), mostly represented by Cenostigma bracteosum (17); and Bignoniaceae, with 20 individuals of Fridericia sp. The species mentioned above have a wide distribution, occurring in the Amazonian vegetation, Cerrado, and Caatinga (BFG, continuously edited). This can reinforce differences in the woody component due to the transition between the vegetation formations of the Amazon forest and Cerrado.

Families Fabaceae, Myrtaceae, and Rubiaceae are also representative in restingas. Their species have a high dispersion capacity and develop in environments with limiting conditions due to water scarcity and low soil fertility. These species are thus more likely to establish in these environments, mainly those of the family Myrtaceae.

The species with the highest IV were Guettarda angelica, Anacardium occidentale, Myrcia splendens, Cenostigma bracteosum, and Fridericia sp., accounting for $54.88 \%$ of the species in the community.

Regarding coverage values (CV), the same species stood out, although in a different order: Anacardium occidentale, Guettarda angelica, Myrcia splendens, Cenostigma bracteosum, and Fridericia sp., highlighting the ecological importance of these species regarding their plant size and tree canopy branches, which allow shading for the development of other species and contribute to the spatial organization of individuals in the area. 
Table 1. Phytosociological parameters of the species sampled in the restinga of Itatinga, Alcântara city, Maranhão State, Brazil. $\mathrm{n}=$ number of individuals per species, $\mathrm{RD}=$ relative density, $\mathrm{AF}=$ absolute frequency, $\mathrm{RF}=$ relative frequency, $\mathrm{RDo}=$ relative dominance, IV = importance value, $\mathrm{CV}=$ coverage value. Species ordered from the value of $\mathrm{n}$.

\begin{tabular}{|c|c|c|c|c|c|c|c|c|}
\hline Specie & Family & $\mathrm{n}$ & $\mathrm{AF}$ & $\mathrm{RF}$ & $\mathrm{RD}$ & RDo & IV & $\mathrm{CV}$ \\
\hline Guettarda angelica Mart. ex Müll.Arg. & Rubiaceae & 43 & 50 & 16.34 & 21.50 & 12.02 & 49.86 & 33.52 \\
\hline Fridericia sp. & Bignoniaceae & 20 & 26 & 8.50 & 10.00 & 1.73 & 20.23 & 11.73 \\
\hline Cenostigma bracteosum (Tul.) Gagnon \& G. P. Lewis & Fabaceae & 17 & 24 & 7.84 & 8.50 & 8.86 & 25.21 & 17.36 \\
\hline Myrcia splendens (Sw.) DC. & Myrtaceae & 14 & 22 & 7.19 & 7.00 & 11.25 & 25.44 & 18.25 \\
\hline Eugenia stictopetala Mart. ex DC. & Myrtaceae & 11 & 20 & 6.54 & 5.50 & 2.33 & 14.36 & 7.83 \\
\hline Mouriri guianensis Aubl. & Melastomatacae & 10 & 20 & 6.54 & 5.00 & 1.87 & 13.41 & 6.87 \\
\hline Manilkara bidentata (A.DC.) A.Chev. & Sapotaceae & 9 & 14 & 4.58 & 4.50 & 1.24 & 10.31 & 5.74 \\
\hline Agonandra brasiliensis Miers ex Benth. \& Hook.f. & Opiliaceae & 9 & 14 & 4.58 & 4.50 & 0.69 & 9.76 & 5.19 \\
\hline Tocoyena sellowiana (Cham. \& Schltdl.) K.Schum. & Rubiaceae & 7 & 10 & 3.27 & 3.50 & 0.79 & 7.55 & 4.29 \\
\hline Cordiera myrciifolia (K.Schum.) C.H.Perss. \& Delprete & Rubiaceae & 7 & 8 & 2.61 & 3.50 & 0.16 & 6.27 & 3.66 \\
\hline Faramea nitida Benth. & Rubiaceae & 6 & 10 & 3.27 & 3.00 & 0.27 & 6.53 & 3.27 \\
\hline Anacardium occidentale $\mathrm{L}$. & Anacardiaceae & 5 & 10 & 3.27 & 2.50 & 38.14 & 43.91 & 40.64 \\
\hline Guettarda spruceana Müll.Arg. & Rubiaceae & 4 & 8 & 2.61 & 2.00 & 1.55 & 6.16 & 3.55 \\
\hline Conocarpus erectus $\mathrm{L}$. & Combretaceae & 4 & 6 & 1.96 & 2.00 & 1.76 & 5.72 & 3.76 \\
\hline Centrolobium sp. & Fabaceae & 3 & 4 & 1.31 & 1.50 & 5.14 & 7.95 & 6.64 \\
\hline Maytenus erythroxyla Reissek & Celastraceae & 3 & 4 & 1.31 & 1.50 & 2.59 & 5.40 & 4.09 \\
\hline Byrsonima crassifolia (L.) Kunth & Malpighiaceae & 3 & 6 & 1.96 & 1.50 & 0.91 & 4.37 & 2.41 \\
\hline Manilkara triflora (Allemão) Monach. & Sapotaceae & 3 & 6 & 1.96 & 1.50 & 0.52 & 3.99 & 2.02 \\
\hline Sapium glandulosum (L.) Morong & Euphorbiaceae & 2 & 4 & 1.31 & 1.00 & 5.01 & 7.32 & 6.01 \\
\hline Erythroxylum barbatum O.E.Schulz & Erythroxylaceae & 2 & 4 & 1.31 & 1.00 & 0.32 & 2.63 & 1.32 \\
\hline Manihot tristis Müll.Arg. & Euphorbiaceae & 2 & 4 & 1.31 & 1.00 & 0.26 & 2.57 & 1.26 \\
\hline Pseudima frutescens (Aubl.) Radlk. & Sapindaceae & 2 & 4 & 1.31 & 1.00 & 0.26 & 2.57 & 1.26 \\
\hline Dalbergia ecastaphyllum (L.) Taub. & Fabaceae & 2 & 4 & 1.31 & 1.00 & 0.24 & 2.55 & 1.24 \\
\hline Cynophalla flexuosa (L.) J.Presl & Capparaceae & 2 & 4 & 1.31 & 1.00 & 0.22 & 2.52 & 1.22 \\
\hline Indeterminate 25 & - & 1 & 2 & 0.65 & 0.50 & 0.49 & 1.65 & 0.99 \\
\hline Indeterminate 6 & - & 1 & 2 & 0.65 & 0.50 & 0.48 & 1.63 & 0.98 \\
\hline Chloroleucon acacioides (Ducke) Barneby \& J.W.Grimes & Fabaceae & 1 & 2 & 0.65 & 0.50 & 0.38 & 1.53 & 0.88 \\
\hline Alibertia edulis (Rich.) A.Rich. & Rubiaceae & 1 & 2 & 0.65 & 0.50 & 0.15 & 1.31 & 0.65 \\
\hline Fabaceae 2 & Fabaceae & 1 & 2 & 0.65 & 0.50 & 0.15 & 1.31 & 0.65 \\
\hline Coccoloba latifolia Lam. & Polygonaceae & 1 & 2 & 0.65 & 0.50 & 0.07 & 1.23 & 0.57 \\
\hline Erythroxylum pungens O.E.Schulz & Erythroxylaceae & 1 & 2 & 0.65 & 0.50 & 0.06 & 1.21 & 0.56 \\
\hline Indeterminate 7 & - & 1 & 2 & 0.65 & 0.50 & 0.05 & 1.21 & 0.55 \\
\hline Indeterminate 13 & - & 1 & 2 & 0.65 & 0.50 & 0.02 & 1.17 & 0.52 \\
\hline Anacardiaceae 1 & Anacardiaceae & 1 & 2 & 0.65 & 0.50 & 0.01 & 1.17 & 0.51 \\
\hline
\end{tabular}

Table 2. Frequency (absolute and relative) of individuals of restinga species per height and diameter classes; Itatinga beach, Alcântara city, Maranhão State, Brazil.

\begin{tabular}{lc||ll}
\hline \multicolumn{4}{c}{ Plant height $(\mathrm{m})$} \\
\hline $1.0-2.0$ & $12(6.0 \%)$ & $8.1-9.0$ & $6(3.0 \%)$ \\
$2.1-3.0$ & $41(20.5 \%)$ & $9.1-10.0$ & $1(0.5 \%)$ \\
$3.1-4.0$ & $28(14 \%)$ & $10.1-11.0$ & $0(0.0 \%)$ \\
$4.1-5.0$ & $65(32.5 \%)$ & $11.1-12.0$ & $1(0.5 \%)$ \\
$5.1-6.0$ & $23(11.5 \%)$ & $12.1-13.0$ & $1(0.5 \%)$ \\
$6.1-7.0$ & $13(6.5 \%)$ & $>13.0$ & $1(0.5 \%)$ \\
$7.1-8.0$ & $8(4.0 \%)$ & \\
\hline \multicolumn{4}{c}{ Diameter $(\mathrm{cm})$} \\
\hline $3-13$ & $139(69.5 \%)$ & $44-54$ & $1(0.5 \%)$ \\
$14-23$ & $37(18.5 \%)$ & $55-63$ & $4(2.0 \%)$ \\
$24-33$ & $10(5.0 \%)$ & 64 or more & $1(0.5 \%)$ \\
$34-43$ & $8(4.0 \%)$ & & \\
\hline
\end{tabular}

Species Anacardium occidentale also stood out among the species of greatest importance value (IV) in the restinga of Curupu, Maranhão State (Machado \& Almeida Jr., 2019). This species is common in different areas of the northeast coast, as recorded for Rio Grande do Norte (Medeiros et al., 2014), Pernambuco (Cantarelli et al., 2012), and Piauí (Santos-Filho et al., 2013). Its predominance in restingas occurs because it is a pioneer species, occupying edges of forest fragments, clearings, and open canopy areas (Zickel $e t$ al., 2015). Species Cenostigma bracteosum, common in the Caatinga and Cerrado domains, stood out among the species of highest IV in the restinga. This highlight is possibly linked to growth strategies in the succession process, with high resistance to drought and the ability to compete for light, which makes it a dominant species (Sampaio, Araújo, Salcedo \& Tiessen, 1998). Species Guettarda angelica, typical of the Caatinga biome, also stood out, establishing and developing in the coastal areas of Maranhão State. 
Species Guettarda angelica, Myrcia splendens, Cenostigma bracteosum, Fridericia sp., Eugenia stictopetala, and Mouriri guianensis were the most frequent. In turn, species Alibertia edulis, Chloroleucon acacioides, Coccoloba latifolia, and Erythroxylum pungens were considered rare (Martins, 1991) due to the lower representativeness in the area, with only one individual.

The Shannon diversity index $\left(\mathrm{H}^{\prime}\right)$ was 2.92 nat. ind ${ }^{-1}$, and the Pielou's evenness index ( $\mathrm{J}$ ') was 0.83 . Despite restinga being considered a low diversity ecosystem, the value recorded for the study area was close to the values found by Machado and Almeida Jr. (2019), who recorded H' of 2.9 nat.ind $^{-1}$ in the restinga of Curupu, Maranhão State; and Santos-Filho, Almeida Jr. \& Zickel (2013), who recorded H' of 2.44 nat.ind $^{-}$ ${ }^{1}$ in Parnaíba, 2.18 nat.ind $^{-1}$ in Luiz Correia, and 2.22 nat.ind $^{-1}$ in Ilha Grande, all representing the coast of Piauí State. According to Corsini et al. (2014), the equivalent values can indicate more uniform communities and a balance in the plant structure, even if in a more attenuated way, with few groups dominating. It is worth noting, therefore, that the values found in restingas should be interpreted with caution in view of the limitations imposed by environmental stresses for plant growth.

Among the species mentioned above, it is worth mentioning Sapium glandulosum, a common species in Cerrado areas that was collected in a restinga. Furthermore, species Manilkara bidentata, common in the Amazon forest, was also collected in a restinga, which reinforces the influence of neighboring ecosystems on the colonization of coastal vegetation in Maranhão State (Almeida Jr. et al., 2011; Serra et al., 2016). Considering the species distribution along the northeast coast, the presence of these species in restingas supports the hypothesis that coastal vegetation may provide species to compose corridors in ecotonal environments (Castro, Moro \& Menezes, 2012).

\section{Conclusion}

The studied area presented species richness and diversity values close to those of other restingas in the northeast. The closed shrublands physiognomy in the Itatinga restinga is characterized by medium vegetation; taller trees showing spaced canopy; lack of emerging species; thinner stems; and branched shrubs. This makes the spatial arrangement of individuals looks closer and denser.

\section{Acknowledgments}

The authors would like to thank the National Council for Scientific and Technological Development (CNPq) and the Federal University of Maranhão (UFMA) for their Scientific Initiation scholarship (PIBIC). To the Foundation for the Support of Research and Scientific and Technological Development of Maranhão (FAPEMA) for the financing of the project and the Productivity Scholarship of the first author and Coordination for the Improvement of Higher Education Personnel (CAPES).

\section{References}

Almeida Jr., E. B., Olivo, M. A., Araújo, E. L., \& Zickel, C. S. (2009). Caracterização da vegetação de restinga da RPPN de Maracaípe,
Pernambuco, com base na fisionomia, flora, nutrientes do solo e lençol freático. Acta Botanica Brasilica, 23(1): 36-48. doi: 10.1590/S010233062009000100005

Almeida Jr., E. B., Santos-Filho, F. S., \& Zickel, C. S. (2011). Magnoliophyta, Ericales, Sapotaceae, Manilkara cavalcantei pires and Rodrigues ex T. D. Penn: first occurrence for northeastern Brazil. Checklist, 7(1): 53-54. doi: 10.15560/7.1.53

Amorim, I. F. F., Santos-Filho, F. S., \& Almeida Jr., E. B. (2016b). Fitossociologia do estrato herbáceo de uma área de dunas em Araçagi, Maranhão. In: E.B. Almeida Jr., \& F.S. Santos-Filho (Orgs.), Biodiversidade do Meio Norte do Brasil: conhecimentos ecológicos e aplicações. (1a ed., Cap. 2, pp. 29-44). Curitiba, Editora CRV.

Angiosperm Phylogeny Group IV (2016). An update of the angiosperm phylogeny group classification for the orders and families of flowering plants: APG IV. Botanical Journal of the Linnean Society, 181: 1-20. doi: 10.1111/boj. 12385

Araújo, A. C. M., Silva, A. N. F., \& Almeida Jr., E. B. (2016). Caracterização estrutural e status de conservação do estrato herbáceo de dunas da praia de São Marcos, Maranhão, Brasil. Acta Amazonica, 46(3): 247-258. doi: 10.1590/1809-4392201504265

BFG, continuamente editado. Myrtaceae. Lista de espécies da flora do Brasil. Jardim Botânico do Rio de Janeiro.

Cantarelli, J. R. R., Almeida Jr., E. B., Santos-Filho, F. S., \& Zickel, C. S. (2012). Tipos fitofisionômicos e florística da restinga da APA de Guadalupe, Pernambuco, Brasil. Insula, 41: 95-117. doi: 10.5007/21784574.2012n41p95

Castro, A. S. F., Moro, M. F., \& Menezes, M. O. T. (2012). O complexo vegetacional da zona litorânea no Ceará: Pecém, São Gonçalo do Amarante. Acta Botanica Brasilica, 26(1): 108-124. doi: 10.1590/S0102-33062012000100013

Corsini, C. R., Scolforo, J. R. S., Oliveira, A. D., Mello, J. M., \& Machado, E. L. M. (2014). Diversidade e similaridade de fragmentos florestais nativos situados na região Nordeste de Minas Gerais. Cerne, 20: 1-10. doi: 10.1590/S0104-77602014000100001

Cottam, G., \& Curtis, J. T. (1956). The use of distance measures in phytosociological sampling. Ecology, 37(3): 451-460. doi: $10.2307 / 1930167$

Dias, H. M., \& Araujo, D. S. D. (2017). Estrutura do estrato lenhoso de uma comunidade arbustiva fechada sobre cordão arenoso na restinga da Marambaia - RJ. Ciência Florestal, 27(4): 1129-1142. doi: $10.5902 / 1980509830290$

El-Robrini et al. (2006). Erosão e progradação do litoral brasileiro: Maranhão Brasília: editora São Paulo.

Instituto Nacional de Meteorologia - INMET (2018). Banco de Dados Meteorológicos para Ensino e Pesquisa - BDMEP

Koppen, W. (1948). Climatologia: con un estudio de los climas de la tierra. (1a ed.). México: Fondo de Cultura Economica.

Machado, M. A., \& Almeida Jr., E. B. (2019). Spatial structure, diversity and edaphic factors of an area of Amazonian coast vegetation in Brazil. Journal of the Torrey Botanical Society, 146(1): 58-68. doi: 10.3159/TORREY-D-18-00025.1

Martins, F. R. (1991). Estrutura de uma floresta mesófila. Campinas. Editora da Universidade Estadual de Campinas. 246p.

Mattos, C. M. J., Silva, W. L. S., Carvalho, C. S., Lima, A. N., Faria, S. M., \& Lima, H. C. (2018). Flora das cangas da serra dos Carajás, Pará, Brasil Leguminosae. Rodriguésia, 69(3): 1147-1220. doi: 10.1590/2175-7860201869323

Medeiros, D. P. W.; Almeida Jr., E. B.; Abreu, M. C.; Santos-Filho, F. S.; \& Zickel, C. S. (2014). Riqueza e caracterização da estrutura lenhosa da vegetação de restinga de Baia Formosa, RN, Brasil. Pesquisas, Botânica, 65, 183-199.

Mori, L. A., Silva, L. A., Lisboa, G., \& Coradin, L. (1989). Manual de manejo do herbário fanerogâmico. Ilhéus: Centro de Pesquisa do cacau.

Mueller-Dombois, D., \& Ellenberg, H. (1974). Aims and methods of vegetation ecology. John Wiley \& Sons, New York.

Peixoto, A. L., \& Maia, L. C. (2013). Manual de procedimentos para herbários. Recife: Editora UFPE.

Pessoa, M. C. R., \& Barbosa, M. R. V. (2012). The family Rubiaceae Juss.in 
the Cariri region of Paraíba. Rodriguésia, 63(4): 1019-1037. doi: 10.1590/S2175-78602012000400017

Pinheiro, L. S., Coriolano, L. N., Costa, M. F., \& Dias, J. A. (2008). O nordeste brasileiro e a gestão costeira. Revista de Gestão Costeira Integrada, 8(2): 5-10.

Sampaio, E. V. S. B., Araújo, E. L., Salcedo, I. H., Tiessen, H. (1998). Regeneração da vegetação de caatinga após corte e queima, em Serra Talhada, PE. Pesquisa Agropecuária Brasileira, 33: 621-632.

Santos, J. U. M., Amaral, D. D., Gorayebe, I. S., Bastos, M. N. C., Secco, R. S., Neto, S. V. C., \& Costa, D. C. T. (2003). Vegetação da área de proteção ambiental Jabotitiua-Jatium, município de Viseu, Pará, Brasil. Acta Amazonica, 33(3): 431-444. doi: 10.1590/S0044-59672003000300009

Santos-Filho, F. S., Almeida Jr., E. B., Soares, C. J. R. S., \& Zickel, C. S. (2010). Fisionomias das restingas do Delta do Parnaíba, Nordeste, Brasil. Revista Brasileira de Geografia Física, 3(3): 218-227.

Santos-Filho, F. S., Almeida Jr., E. B., \& Zickel, C. S. (2013). Do edaphic aspects alter vegetation structures in the Brazilian restinga? Acta Botanica Brasilica, 27(3): 613-623. doi: 10.1590/S0102-33062013000300019

Santos, C. R., Amorim, I. F. F., \& Almeida Jr., E. B. (2019). Caracterização fitossociológica do componente halófilo-psamófilo em uma área de dunas, Maranhão, Brasil. Boletim do Laboratório de Hidrobiologia, 29(1): 1-8.

Serra, F. C. V., Lima, P. B., \& Almeida Jr., E. B. (2016). Species richness in restinga vegetation on the eastern of Maranhão State, Brazil. Acta Amazonica, 46(3): 271-280. doi: 10.1590/1809-4392201504704

Shepherd, G. J. (2010). FITOPAC. Versão 2.1. Campinas, SP: Universidade Estadual de Campinas - UNICAMP.

Silva, A. N. F., Araujo, A. C. M., \& Almeida Jr., E. B. (2016). Flora fanerogâmica das dunas da praia de São Marcos, São Luís, Maranhão. In: E.B. Almeida Jr., \& F.S. Santos-Filho (Orgs.): Biodiversidade do Meio Norte do Brasil: conhecimentos ecológicos e aplicações. (1a ed., Cap. 1, pp. 11-28). Curitiba, Editora CRV.

Trindade, J. R., Rosário, A. S., \& Santos, J. U. M. (2018). Flora das cangas da serra dos Carajás, Pará, Brasil: Myrtaceae. Rodriguésia, 69(3): 1259-1277. doi: 10.1590/2175-7860201869327

Zappi, D. C., Miguel, L. M., Sobrado, S. V. \& Salas, R. M. (2017). Flora das cangas da serra dos Carajás, Pará, Brasil: Rubiaceae. Rodriguésia, 68(3): 1091-1137. doi: 10.1590/2175-7860201768347

Zickel, C. S., Vicente, A., Silva, S. S. L., Santos-Filho, F. S., Soares, C. J. R. S., \& Almeida Jr., E. B. (2015). Vegetação lenhosa de uma restinga em Pernambuco: descrição estrutural e similaridade. Pesquisas Botânica, 68: 271-285.

License: Creative Commons CC BY 4.0

This article was published with open access for distribution under the terms of the Creative Commons Attribution License, which allows unrestricted use, distribution, and reproduction in any medium, provided the original work is properly cited. 